Paediatr Croat. 2015;59:32-8

\title{
Lavage with diluted surfactant as a treatment option for atelectasis in pediatric intensive care patients
}

\author{
Maja Karaman Ilić ${ }^{1}$, Goran Madžarac², Irena Babić3 , Boris Milavićc
}

The aim of this study was to assess the effect of fiberoptic aspiration and diluted surfactant administration on affected lungs in children with atelectasis. A convenience sample of 18 mechanically ventilated children were analyzed in this single center prospective study. The children had first been treated unsuccessfully by respiratory physical therapy, after which they underwent fiberoptic aspiration. After aspiration, nine children were randomly selected to receive therapeutic lavage with diluted porcine surfactant; the remaining nine received the same quantity of saline solution. Several parameters of /ung function, including positive end-expiratory pressure (PEEP) and oxygenation index (Ol), as well as lung $x$-ray images were determined before aspiration and lavage, then at 6 and $12 \mathrm{~h}$ after lavage. In both groups, most of the measured parameters showed improvement from baseline at $6 \mathrm{~h}$ after treatment. Improvement was even more significant $12 \mathrm{~h}$ after treatment. The surfactant group showed significant improvement in comparison to the saline group. The impact of surfactant administration was most visible on the following parameters $12 \mathrm{~h}$ after treatment ( $p<0.001$ in all cases): PEEP 5.22 (SD 0.44) in the saline group vs. 3.44 (SD 0.73) in the surfactant group; OI 3.84 (SD 1.13) vs. 2.1 (SD 0.38); and mean airway pressure (MAP) 8.56 (SD 0.88) vs. 6.33 (SD 0.5). In conclusion, fiberoptic aspiration is an efficient treatment in pediatric intensive care patients. The observed beneficial effects of therapeutic lavage with diluted surfactant should be confirmed prospectively in a larger number of patients.

Keywords: bronchoalveolar lavage; pulmonary surfactants; pulmonary atelectasis; intensive care units, pediatric

\section{INTRODUCTION}

Atelectasis refers to the lack of gas exchange in collapsed, airless regions of the lung (1). The condition itself is not a disease, but is associated with several pulmonary and chest disorders and is a symptom of the underlying disease (2). Clinical manifestations of atelectasis depend on the underlying cause, as well as on the degree of volume loss within the lung. When atelectasis is relatively small and associated with little physiological impairment, there may be no signs or symptoms. In massive unilateral atelectasis, however, tracheal deviation and a shift in heart sounds towards the atelectatic side may occur (3).

The standard treatment for atelectasis is respiratory physical therapy, including percussion, vibration, aspiration, aerosolized bronchodilators and positional drainage. Fiberoptic aspiration, alone or with therapeutic saline lavage, is used when these procedures are ineffective. Bronchoscopic aspiration is a safe bedside procedure, even in pediatric population $(4,5)$.

Lobar atelectasis is frequently seen in pediatric patients undergoing mechanical ventilation (6). At least $8 \%$ of children on mechanical ventilation develop pulmonary atelectasis, with a concomitant increase in the morbidity and length of

\footnotetext{
'Department of Anesthesiology, Resuscitation and Intensive Care, University Hospital Centre Zagreb, Croatia

2 Department of Thoracic Surgery, University Hospital Centre Zagreb,

Croatia

${ }^{3}$ ENT Department, Zagreb Children's Hospital, Zagreb, Croatia

${ }^{4}$ Faculty of Kinesiology, University of Split, Split, Croatia
}

\section{Correspondence to:}

Maja Karaman Ilić, MD, PhD, Department of Anesthesiology, Resuscitation and Intensive Care, Zagreb University Hospital Center, Kišpatićeva 12, 10000 Zagreb, Croatia, e-mail: majakilic1@gmail.com

Primljeno/Received: 11. 11. 2014., Prihvaćeno/Accepted: 19. 2. 2015. 
hospitalization (7). The most common types of atelectasis in children are resorption atelectasis following airway obstruction or adhesive atelectasis due to surfactant deficiency or dysfunction (8). In cases of the latter, surfactant administration as supplementary therapy may help minimize changes in surface tension and improve mucus transport within the narrow pediatric airways $(4,9)$. According to Strohmaier (10), lavage with diluted surfactant may not only replenish the missing endogenous surfactant, but it may also remove pathologic material more effectively than saline lavage because the washing agent is more uniformly distributed.

The effect of therapeutic lavage with diluted surfactant is still questionable. Several studies have shown lavage with diluted surfactant to be more therapeutically effective than conventional bolus or aerosol therapy (11-13). However, studies on pediatric and adult patients with different indications for exogenous surfactant application have given contradictory results (14-22). For example, the use of surfactant shows promise for treating severe bronchiolitis and acute respiratory distress syndrome (ARDS) (23), but its use in patients with bronchopneumonia remains controversial.

The present study was designed to investigate whether aspiration followed by therapeutic lavage with diluted exogenous surfactant can effectively treat atelectasis in pediatric patients on long-term ventilation.

\section{MATERIALS AND METHODS}

\section{Patient recruitment}

This prospective study was carried out in the intensive care unit (ICU) of the Zagreb Children's Hospital. The Hospital Ethics Committee approved the study, and a written informed consent was obtained from the parents. Patient characteristics (demographic data and diagnoses) are shown in Table 1.

Out of 42 children mechanically ventilated in the ICU during the study period, 18 of 25 patients that developed lobar atelectasis were enrolled in the study. Inclusion criteria were

TABLE 1. Patient characteristics: demographic data and diagnoses

\begin{tabular}{lll}
\hline & $\begin{array}{l}\text { Control } \\
\text { group }\end{array}$ & $\begin{array}{l}\text { Experimental } \\
\text { group }\end{array}$ \\
Age (yrs) & $4.7 \pm 3.0$ & $4.4 \pm 3.4$ \\
Gender (F/M) & $2 / 7$ & $4 / 5$ \\
Diagnosis: & & \\
Spinal muscular atrophy & 3 & 2 \\
Trauma (head trauma/polytrauma) & $2 / 1(67 \% / 33 \%)$ & $1 / 1(50 \% / 50 \%)$ \\
Neuroblastoma & 2 & 1 \\
Posterior fossa tumor & & 1 \\
Combustion & 1 & 2 \\
Adult respiratory distress syndrome & & 1
\end{tabular}

pediatric status, presence of atelectasis, and mechanical ventilation longer than two weeks.

Atelectasis was diagnosed based on clinical and radiological criteria. The clinical criteria were fever, crepitation, partial pressure of carbon dioxide $\left(\mathrm{PaCO}_{2}\right) \geq 45 \mathrm{~mm} \mathrm{Hg}(6 \mathrm{kPa})$, peak inspiratory pressure (PIP) $\geq 25$, and partial pressure of arterial oxygen/fraction of inspired oxygen ratio $\left(\mathrm{PaO}_{2} / \mathrm{FiO}_{2}\right) \leq 300$. Radiological criteria included opacification, a shift of the mediastinum, displacement of the interlobar fissure and elevated diaphragm. Laboratory investigations included complete blood count, blood cultures, and culture of airway secretions.

\section{Procedures}

Patients were randomly assigned to either of the two groups using closed envelopes. Both groups were ventilated with a Dräger Medical EVITA 4 (Lübeck, Germany). Peak inspiratory pressure (PIP) and positive end-expiratory pressure (PEEP) were adjusted to achieve a tidal volume of $7-8 \mathrm{~mL} / \mathrm{kg}$ body weight.

No food was given to children through their nasogastric tube for at least $4 \mathrm{~h}$ prior to bronchoscopy. During the aspiration and lavage, inspiratory oxygen fraction $\left(\mathrm{FiO}_{2}\right)$ was 1.0. Procedures were performed through tracheostomy or endotracheal tube with an Olympus BF-3C30 bronchoscope. Lidocaine (2\%, maximum dose of $1 \mathrm{mg} / \mathrm{kg}$ ) was used for local anesthesia of the carina and to prevent straining. Oxygen saturation $\left(\mathrm{SpO}_{2}\right)$, end-tidal carbon dioxide in expired air (etCO $\mathrm{C}_{2}$ ) and invasive arterial pressure (ABP) were monitored throughout the procedure. Multiple intravenous (IV) accesses were secured. If $\mathrm{SpO}_{2}$ fell below 85\%, the procedures were stopped until the level recovered. All procedures were performed in the ICU or the operating room.

After fiberoptic aspiration, therapeutic lavage of the affected area was carried out using solutions pre-warmed to body temperature. Children in the control group received isotonic saline, while those in the surfactant group received an equal volume of porcine surfactant diluted in saline solution (5 mg Curosurf/mL; Curosurf ${ }^{\oplus}$, Chiesi, Italy). The whole amount of fluid surfactant was given instantly in the main bronchus of the affected lung. The mean volume (SD) given to each group was 34.3 (SD 13.76) $\mathrm{mL}$, corresponding to a mean (SD) of $3.199(0.411) \mathrm{mL} / \mathrm{kg}$ body weight. The mean amount (SD) of surfactant delivered to the experimental group was 15.66 (SD 2.33) mg Curosurf/kg body weight.

\section{Measurements}

Several gas exchange and pulmonary mechanic parameters were measured before and after aspiration and lavage: PIP 
in $\mathrm{cm} \mathrm{H} \mathrm{H}_{2} \mathrm{O}$, PEEP in $\mathrm{cm} \mathrm{H} \mathrm{H}_{2} \mathrm{O}, \mathrm{PaO}_{2} / \mathrm{FiO}_{2}$, oxygenation index $(\mathrm{OI}), \mathrm{PaCO}_{2}$ in $\mathrm{mm} \mathrm{Hg}$, and mean airway pressure (MAP) in $\mathrm{cm} \mathrm{H}_{2} \mathrm{O}$. These measurements were made before treatment (baseline) and at 6 and $12 \mathrm{~h}$ after treatment. During the observation period, we minimized aspiration of the airways in order to keep the lavage solution at the site of action.

Descriptive lung x-ray evaluations were carried out at baseline and $12 \mathrm{~h}$ after treatment. Radiograms were independently assessed by two radiologists blinded to patient assignments.

\section{Statistics}

ANOVA tests were performed to determine significant differences in mean values between the study groups. Dependent-sample t-tests were used to test differences in mean values between baseline and $6 \mathrm{~h}$ post-treatment, as well as between baseline and $12 \mathrm{~h}$ post-treatment. Independentsample t-tests were used to test differences in mean values between the control and experimental group for each of the three sets of measurements separately (baseline, $6 \mathrm{~h}$ post-treatment and $12 \mathrm{~h}$ post-treatment).

\section{RESULTS}

Lung x-ray evaluations were carried out at baseline and $12 \mathrm{~h}$ after treatment. Since the evaluations were qualitative, they were difficult to analyze statistically. Chest $x$-ray analysis indicated improvements in both groups, ranging from $20 \%$ to 90\%. Several lung function parameters were measured, including PIP ( $\left.\mathrm{cm} \mathrm{H}_{2} \mathrm{O}\right), \operatorname{PEEP}\left(\mathrm{cm} \mathrm{H}_{2} \mathrm{O}\right), \mathrm{PaO}_{2}(\mathrm{~mm} \mathrm{Hg}) / \mathrm{FiO}_{2^{\prime}} \mathrm{Ol}$, $\mathrm{SpO}_{2}, \mathrm{PaCO}_{2}(\mathrm{~mm} \mathrm{Hg})$, and MAP $\left(\mathrm{cm} \mathrm{H}_{2} \mathrm{O}\right)$. The two groups did not differ significantly in any of the parameters at baseline (Table 2).

Both groups showed significant improvement in multiple lung function parameters between baseline and $6 \mathrm{~h}$ after

TABLE 2. Comparison of baseline lung function parameters between control and surfactant groups

\begin{tabular}{lll}
\hline & $\begin{array}{l}\text { Control } \\
\text { group }\end{array}$ & $\begin{array}{l}\text { Experimental } \\
\text { group }\end{array}$ \\
$\mathrm{PIP}\left(\mathrm{cm} \mathrm{H}_{2} \mathrm{O}\right)$ & 29.11 & 29.56 \\
$\mathrm{PEEP}\left(\mathrm{cm} \mathrm{H}_{2} \mathrm{O}\right)$ & 6.44 & 6.56 \\
$\mathrm{PaO}_{2} / \mathrm{FiO}_{2}(\mathrm{~mm} \mathrm{Hg})$ & 210.18 & 205.97 \\
$\mathrm{OI}$ & 7.13 & 7.20 \\
$\mathrm{SpO}_{2}$ & 93.22 & 93.56 \\
$\mathrm{PaCO}_{2}(\mathrm{~mm} \mathrm{Hg}$ & 63.00 & 56.44 \\
$\left.\mathrm{MAP}_{(\mathrm{cm} \mathrm{H}} \mathrm{O}\right)$ & 14.44 & 14.67
\end{tabular}

$\mathrm{PIP}=$ peak inspiratory pressure; $\mathrm{PEEP}=$ positive end expiratory pressure; $\mathrm{PaO}_{2} / \mathrm{FiO}_{2}=$ partial pressure of arterial oxygen/fraction of inspired oxygen ratio; $\mathrm{Ol}=$ oxygenation index; $\mathrm{SpO}_{2}=$ oxygen saturation; $\mathrm{PaCO}_{2}=$ partial pressure of carbon dioxide; $\mathrm{MAP}=$ mean airway pressure
TABLE 3. Comparison of lung function parameters in control group before and after treatment

\begin{tabular}{llll}
\hline & $\begin{array}{l}\text { Baseline } \\
\text { measurement }\end{array}$ & $\begin{array}{l}6 \mathrm{~h} \text { after } \\
\text { treatment }\end{array}$ & $\begin{array}{l}12 \mathrm{~h} \text { after } \\
\text { treatment }\end{array}$ \\
$\mathrm{PIP}\left(\mathrm{cm} \mathrm{H}_{2} \mathrm{O}\right)$ & 29.11 & $26.67^{\mathrm{a}}$ & $26.33^{\mathrm{b}}$ \\
$\mathrm{PEEP}\left(\mathrm{cm} \mathrm{H}_{2} \mathrm{O}\right)$ & 6.44 & $5.22^{\mathrm{a}}$ & $5.22^{\mathrm{a}}$ \\
$\mathrm{PaO}_{2} / \mathrm{FiO}_{2}(\mathrm{~mm} \mathrm{Hg})$ & 210.18 & $226.62^{\mathrm{a}}$ & $238.65^{\mathrm{a} 1}$ \\
$\mathrm{OI}$ & 7.13 & $4.74^{\mathrm{b}}$ & $3.84^{\mathrm{b} 1}$ \\
$\mathrm{SpO}_{2}$ & 93.22 & $96.67^{\mathrm{a}}$ & $97.00^{\mathrm{a}}$ \\
$\mathrm{PaCO}_{2}(\mathrm{~mm} \mathrm{Hg}$ & 63.00 & $57.56^{\mathrm{a}}$ & $55.56^{\mathrm{a}}$ \\
$\mathrm{MAP}\left(\mathrm{cm} \mathrm{H}_{2} \mathrm{O}\right)$ & 14.44 & $10.67^{\mathrm{b}}$ & $8.56^{\mathrm{b} 2}$
\end{tabular}

$\mathrm{PIP}=$ peak inspiratory pressure; $\mathrm{PEEP}=$ positive end expiratory pressure; $\mathrm{PaO}_{2} / \mathrm{FiO}_{2}=$ partial pressure of arterial oxygen/fraction of inspired oxygen ratio; $\mathrm{Ol}=$ oxygenation index; $\mathrm{SpO}_{2}=$ oxygen saturation; $\mathrm{PaCO}_{2}=$ partial pressure of carbon dioxide; MAP = mean airway pressure

${ }^{a}$ statistical difference when compared to the baseline measurement $p<0.01$; ${ }^{b}$ statistical difference when compared to the baseline measurement $p<0.001$; 'statistical difference between second and third measurement $p<0.05 ;{ }^{2}$ statistical difference between second and third measurement $p<0.001$

TABLE 4. Comparison of lung function parameters in surfactant group before and after treatment

\begin{tabular}{llll}
\hline & $\begin{array}{l}\text { Baseline } \\
\text { measurement }\end{array}$ & $\begin{array}{l}6 \mathrm{~h} \text { after } \\
\text { treatment }\end{array}$ & $\begin{array}{l}12 \mathrm{~h} \text { after } \\
\text { treatment }\end{array}$ \\
$\mathrm{PIP}\left(\mathrm{cm} \mathrm{H}_{2} \mathrm{O}\right)$ & 29.56 & $24.67^{\mathrm{b}}$ & $24.00^{\mathrm{b} 1}$ \\
$\mathrm{PEEP}\left(\mathrm{cm} \mathrm{H}_{2} \mathrm{O}\right)$ & 6.56 & $4.67^{\mathrm{b}}$ & $3.44^{\mathrm{b} 2}$ \\
$\mathrm{PaO}_{2} / \mathrm{FiO}_{2}(\mathrm{~mm} \mathrm{Hg})$ & 205.97 & $251.94^{\mathrm{a}}$ & $297.67^{\mathrm{b} 3}$ \\
$\mathrm{OI}$ & 7.20 & $3.76^{\mathrm{b}}$ & $2.10^{\mathrm{b} 3}$ \\
$\mathrm{SpO}_{2}$ & 93.56 & $98.00^{\mathrm{a}}$ & $98.67^{\mathrm{a}}$ \\
$\mathrm{PaCO}_{2}\left(\mathrm{~mm} \mathrm{Hg}^{\mathrm{b}}\right)$ & 56.44 & $43.44^{\mathrm{b}}$ & $41.33^{\mathrm{b}}$ \\
$\mathrm{MAP}\left(\mathrm{cm} \mathrm{H}_{2} \mathrm{O}\right)$ & 14.67 & $9.22^{\mathrm{b}}$ & $6.33^{\mathrm{b} 3}$
\end{tabular}

PIP-peak inspiratory pressure, PEEP- positive end expiratory pressure, $\mathrm{PaO}_{2} / \mathrm{FiO}_{2}$ - partial pressure of arterial oxygen/fraction of inspired oxygen ratio, $\mathrm{Ol}$ - oxygenation index, $\mathrm{SpO}_{2}$ - oxygen saturation, $\mathrm{PaCO}_{2}$ - partial pressure of carbon dioxide, MAP- mean airway pressure

${ }^{a}$ statistical difference when compared to the baseline measurement $p<0.01$; ${ }^{b}$ statistical difference when compared to the baseline measurement $p<0.001$; 'statistical difference between second and third measurement $p<0.05 ;{ }^{2}$ statistical difference between second and third measurement $p<0.01 ;{ }^{3}$ statistical difference between second and third measurement $p<0.001$

treatment, which increased further by $12 \mathrm{~h}$ post-treatment. In the control group, $\mathrm{PaO} 2 / \mathrm{FiO} 2, \mathrm{Ol}$, and MAP significantly improved from $6 \mathrm{~h}$ to $12 \mathrm{~h}$ after treatment (Table 3). By $12 \mathrm{~h}$ post-treatment, all measured parameters improved significantly compared to baseline. In the experimental group, most of the parameters were significantly better at $6 \mathrm{~h}$ as compared to baseline: PIP, PEEP, PaO2/FiO2, PaCO2, OI, and MAP (Table 4). Most of the measured parameters in this group further improved significantly between $6 \mathrm{~h}$ and $12 \mathrm{~h}$ post-treatment: PIP, PEEP, $\mathrm{PaO}_{2} / \mathrm{FiO}_{2}$ OI and MAP. By $12 \mathrm{~h}$ post-treatment, all the measured parameters showed significant improvement compared to baseline. 
TABLE 5. Significance of differences in lung function parameters between control and surfactant groups at $6 \mathrm{~h}$ and $12 \mathrm{~h}$ after treatment

\begin{tabular}{lll}
\hline & $\begin{array}{l}\text { Measurements at } 6 \mathrm{~h} \\
P \text { value }\end{array}$ & $\begin{array}{l}\text { Measurements at } 12 \mathrm{~h} \\
P \text { value }\end{array}$ \\
$\mathrm{PIP}\left(\mathrm{cm} \mathrm{H}_{2} \mathrm{O}\right)$ & 0.041 & 0.014 \\
$\mathrm{PEEP}\left(\mathrm{cm} \mathrm{H}_{2} \mathrm{O}\right)$ & 0.106 & 0.000 \\
$\mathrm{PaO}_{2} / \mathrm{FiO}_{2}(\mathrm{~mm} \mathrm{Hg})$ & 0.038 & 0.000 \\
$\mathrm{OI}$ & 0.115 & 0.036 \\
$\mathrm{SpO}_{2}$ & 0.012 & 0.010 \\
$\mathrm{PaCO}_{2}(\mathrm{~mm} \mathrm{Hg})$ & 0.310 & 0.034 \\
$\left.\mathrm{MAP}_{(\mathrm{cm} \mathrm{H}} \mathrm{O}\right)$ & 0.007 & 0.000
\end{tabular}

PIP = peak inspiratory pressure; PEEP = positive end expiratory pressure; $\mathrm{PaO}_{2} / \mathrm{FiO}_{2}=$ partial pressure of arterial oxygen/fraction of inspired oxygen ratio; $\mathrm{Ol}=$ oxygenation index; $\mathrm{SpO}_{2}=$ oxygen saturation; $\mathrm{PaCO}_{2}=$ partial pressure of carbon dioxide; $M A P=$ mean airway pressure; the level of statistical significance was set at $P<0.05$

Comparisons were then carried out between the control and surfactant groups to determine whether the surfactant gave significantly different outcomes. For most of the lung function parameters, values were significantly better in the surfactant group than in the control group at both $6 \mathrm{~h}$ and $12 \mathrm{~h}$ post-treatment (Table 5). At $6 \mathrm{~h}$ after treatment, the surfactant group showed significantly better values of PIP, Ol, PaCO2 and MAP. By $12 \mathrm{~h}$ after treatment, the surfactant group showed better values of these parameters, as well as of PEEP and $\mathrm{PaO} 2 / \mathrm{FiO} 2$.

\section{DISCUSSION}

This study was designed to investigate whether therapeutic lung lavage with diluted surfactant can improve treatment of atelectasis in pediatric patients. The results showed that, although both surfactant and control groups showed improvement in lung function parameters at $6 \mathrm{~h}$ post-treatment and even more by $12 \mathrm{~h}$, the improvement was greater in the surfactant group. In particular, PIP, PEEP, OI, $\mathrm{PaCO}_{2}$ and MAP appeared to improve with surfactant treatment. These values were significantly lower than in the control group at both $6 \mathrm{~h}$ and $12 \mathrm{~h}$ post-treatment.

The fact that mechanical cleaning of the airways by itself was sufficient to improve lung function in the control group, together with the fact that the surfactant group showed greater recovery of lung function, suggests that atelectasis in our patients was partly resorptive due to airway obstruction and partly adhesive due the lack or dysfunction of surfactant.

The driving force for alveolar opening during inspiration is PIP $(24,25)$. PEEP, in contrast, appears to measure the force to maintain alveolar patency $(24,26-28)$. Maintaining high PIP and PEEP in order to open and stabilize collapsed alveo- li can produce over-distention of healthy alveoli due to the variability in alveolar response $(29,30)$. This can result in barotrauma, which should be avoided. Therefore, in the present study, we sought to achieve sufficient PEEP and moderate PIP to ensure adequate oxygenation. At the same time, we sought to avoid high PEEP levels that would interfere with hemodynamic stability or affect the central nervous system function. Achieving a reduction in PEEP is particularly important in hemodynamically unstable patients and in children with elevated intracranial pressure, regardless of its cause. A total of 6 (67\%) and 7 (78\%) patients in our control and surfactant groups, respectively, fell into these two categories.

In the present study, atelectasis treatment was considered successful on the basis of improved oxygenation, as measured by increased SpO2; a decrease in OI, PIP, PEEP, MAP and $\mathrm{PaCO} 2$; and an increase in the $\mathrm{PaO}_{2} / \mathrm{FiO}_{2}$ (P/F) ratio. In atelectasis, blood flow is shunted through non-ventilated areas. When ventilation is restored, $\mathrm{PaO} 2$ and $\mathrm{SpO} 2$ increase, and the inspired $\mathrm{FiO} 2$ may fall. Ol, which is the ratio between the amount of oxygen delivered to the lungs and the amount diffusing into the blood, may be the best indicator of clinical improvement because it integrates airway pressure and oxygenation into a single variable. A reduction in Ol indicates the "opening" of atelectatic parts of lungs, improved gas exchange across alveolar membranes, and shunt reduction. Lungs become more pliant, lowering PIP, PEEP, and the risk of lung collapse. MAP may also decrease. These changes improve the elimination of carbon dioxide, leading to a decrease in PaCO2. Improvement in all measured parameters in both groups $12 \mathrm{~h}$ after treatment indicated that the opened atelectasis remained open and that recurrent atelectasis did not occur.

In cases of adhesive atelectasis, the pathological substrate is mostly resistant to the treatment consisting of percussion, vibration, aspiration, aerosolized bronchodilators, positional drainage and fiberoptic aspiration. After mechanical cleaning, which is sufficient in most cases, in the adhesive type of atelectasis recurrent atelectasis mostly appears because of the lack and/or dysfunction of surfactant and increased surface tendency. Mechanical ventilation further alters the monolayer of surfactant and causes direct alveolar damage, exacerbating surfactant deficiency (5). Being aware of the detrimental impact of mechanical ventilation on surfactant production, we thought that surfactant administration as supplementary therapy might be helpful to our mechanically ventilated patients who developed atelectasis. Our results are consistent with the idea that therapeutic lavage of affected lung areas with diluted surfactant minimizes surface tension and improves mucus transport within the narrow pediatric airways (9). 
Natural porcine surfactant was used in the present study. Natural surfactants, including porcine surfactant, have been found to be effective in increasing arterial oxygenation and alveolar stability, while being less sensitive than artificial ones to inhibition by serum proteins and other inflammatory mediators $(24,25)$. Lavage with diluted surfactant seems to have advantages over the usual methods of surfactant application because it avoids preferential surfactant deposition in lung areas without atelectasis, which can further increase the ventilation imbalance (11-13). Various concentrations of diluted surfactant have been reported in the literature $(2,31-33)$. The concentration in the present study ( $5 \mathrm{mg} / \mathrm{mL}$ ) was lower than the previously reported ones, translating to a mean dose (SD) of 15.66 (2.33) mg surfactant $/ \mathrm{kg}$ body weight. The greatest limitation in studying the effects of higher concentrations is the high cost of the surfactant.

It is important to note that treatment by lavage without surfactant may wash out surfactant from noncompromised areas of the lung instead of replenishing the surfactant pool, thus further aggravating the patient's condition. In the present study, therapeutic lavage of affected areas in both control and surfactant groups was performed with small volumes, so our approach seems unlikely to generate such problems.

\section{CONCLUSION}

The results of this study demonstrate that fiberoptic airway cleaning is an efficient method for atelectasis treatment in children, and that simultaneous therapeutic lavage of atelectatic lung segments with diluted surfactant can improve gas exchange and pulmonary function. For definitive conclusions, larger prospective randomized studies are needed.

\section{NOVČANA POTPORA/FUNDING}

Nema/None

\section{ETIČKO ODOBRENJE/ETHICAL APPROVAL}

Nije potrebno/None

\section{DOPRINOSI AUTORA/DECLARATION OF AUTHORSHIP}

Karaman Ilić M. - ideja i dizajn rada, provedba istraživanja, pisanje rada/idea and design of the study, implementation of research, writing paper

Madžarac G. - obrada podataka, rasprava, pisanje rada/data processing, discussion, writing paper

Babić l. - pomoć kod izvedbe i provedbe istraživanja/assistance in the mplementation of the survey

Milavić B. - statistička obrada podataka/statistical data processing

\section{SUKOB INTERESA/CONFLICT OF INTEREST}

Autori su popunili the Unified Competing Interest form na www.icmje.org/ coi_disclosure.pdf (dostupno na zahtjev) obrazac i izjavljuju: nemaju potporu niti jedne organizacije za objavljeni rad; nemaju financijsku potporu niti jedne organizacije koja bi mogla imati interes za objavu ovog rada u po- sljednje 3 godine; nemaju drugih veza ili aktivnosti koje bi mogle utjecati na objavljeni rad./All authors have completed the Unified Competing Interest form at www.icmje.org/coi_disclosure.pdf (available on request from the corresponding author) and declare: no support from any organization for the submitted work; no financial relationships with any organizations that might have an interest in the submitted work in the previous 3 years; no other relationships or activities that could appear to have influenced the submitted work.

\section{REFERENCES}

1. Raghu Raman TS, Sunil M, Ravikumar, Garcha PS. Atelectasis in children. Indian Pediatr. 1998;35:429-35.

2. Krause MF, von Bismarck P, Oppermann HC, Ankermann T. Bronchoscopic surfactant administration in pediatric patients with persistent lobar atelectasis. Respiration. 2008;75:100-4. http://dx.doi.org/10.1159/000088713

3. Zhang YL, Craster RV, Matar OK. Surfactant driven flows overlying a hydrophobic epithelium: film rupture in presence of slip. J Coloid Interface Sci. 2003;264:160-75. http://dx.doi.org/10.1016/S0021-9797(03)00449-1

4. Tsangaris I, Lekka ME, Kitsiouli E, Constantopoulos S, Nakos G. Bronchoalveolar lavage alterations during prolonged ventilation of patients without acute lung injury. Eur Respir J. 2003;21:495-501. http://dx.doi.org/10.1183/09031936.03.00037902

5. Nussbaum E. Pediatric fiberoptic bronchoscopy: clinical experience with 2,836 bronchoscopies. Ped Crit Care Med. 2002;3:171-6. http://dx.doi.org/10.1097/00130478-200204000-00015

6. Peroni DG, Boner AL. Atelectasis: mechanisms, diagnosis and management. Paediatr Respir Rev. 2000;1:274-8.

7. Thomas K, Habibi P, Britto J, Owens CM. Distribution and pathophyiology of acute lobar collapse in the pediatric intensive care unit. Crit Care Med. 1999;27:1594-7. http://dx.doi.org/10.1097/00003246-199908000-00035

8. Sato S, Kishikawa T. Ultrastructural study of the alveolar lining and the bronchial mucus layer by block staining with oolong tea extract: the role of various surfactant materials. Med Electron Microsc. 2001;34:142-51. http://dx.doi.org/10.1007/s007950170008

9. Bloomfield FH, Teele RL, Voss M, Knight DB, Harding JE. The role of neonatal chest physiotherapy in preventing postextubation atelectsis. J Pediatr. 1998;133: 269-271. http://dx.doi.org/10.1016/S0022-3476(98)70233-1

10. Strohmaier W, Schlag G. Lung lavage with diluted surfactant is as effective as bolus treatment in a long-term aspiration model. Appl Cardiopulm Pathophysiol. 1998;7:17-22.

11. Gommers D, van't Veen A, Verbrugge SJC, Lachmann B. Comparison of eight different surfactant preparations on improvement of blood gases in lung-lavaged rats. Appl Cardiopulm Pathophysiol. 1998;7:95-102.

12. Fernandez-Ruanova MB, Alvarez FJ, Gastiasoro E, Arnaiz A, Robertson B, Curstedt $T$ et al. Comparison of rapid bolus instillation with simplified slow administration of surfactant in lung lavaged rats. Pediatr Pulmonol. 1998;26:129-34. http://dx.doi.org/10.1002/(SICI)1099-0496(199808)26:2<129: :AID-PPUL10>3.0.CO;2-3

13. Nikischin W, Brendel-Muller K, Viemann M, Oppermann H, Schaub J. Improvement in respiratory compliance after surfactant therapy evaluated by new method. Pediatr Pulmonol. 2000;29:276-83. http://dx.doi.org/10.1002/(SICl)1099-0496(200004)29:4<276: :AID-PPUL7>3.0.CO;2-H

14. Keer MH. Surfactant protein levels in severe respiratory syncytial virus infection. Am J Respir Crit Care Med. 1999;159:1115-8. http://dx.doi.org/10.1164/ajrccm.159.4.9709065

15. Dargaville PA, South M, McDougall PN. Surfactant abnormalities in infants with severe viral bronchiolitis. Arch Dis Child. 1996;75:133-6. http://dx.doi.org/10.1136/adc.75.2.133 
16. Lucchetti M, Casiraghi G, Valsecchi R, Galassini E, Marraro G. Porcinederived surfactant treatment of severe bronchiolitis. Acta Anaest Scand. 1998;42:805-10.

http://dx.doi.org/10.1111/j.1399-6576.1998.tb05326.x

17. Vitola LS, Piva JP, Garcia PCR, Bruno F, Miranda AP, Martha VF. Surfactante exógeno no tratamento da bronquiolite viral grave. J Pediatr (Rio J). 2001;77:143-7. http://dx.doi.org/10.2223/JPED.194

18. Mikawa K, Maekawa N. Selective intrabronchial instillation of surfactant in a patient with pneumonia: a preliminary report. Eur Respir J. 1993;6:1563-6.

19. Herting E, Gefeller O, Robertson B, Land M, van Sorenden L, Harms K. Surfactant treatment of neonates with respiratory failure and group $B$ streptococcal infection. Pediatrics. 2000; 106:957-64. http://dx.doi.org/10.1542/peds.106.5.957

20. Anzueto A, Bauglman RP, Guntupallli KK. Aerosolized surfactant in adults with sepsis-induced acute respiratory distress syndrome. N Engl J Med. 1996;334:1417-21 http://dx.doi.org/10.1056/NEJM199605303342201

21. Lopez-Herce J, de Lucas N, Carrillo A, Bustinza A, Moral R. Surfactant treatment for acute respiratory distress syndrome. Arch Dis Child. 1999;80:248-52. http://dx.doi.org/10.1136/adc.80.3.248

22. Willson DF, Zaritsky A, Bauman LA, Dockery K, James RL, Conrad D et al. Instillation of calf lung surfactant extract (calfactant) is beneficial in pediatric acute hypoxemic respiratory failure. Members of the Mid Atlantic Pediatric Critical Care Network. Crit Care Med. 1999;27:188-95. http://dx.doi.org/10.1097/00003246-199901000-00050

23. Freddi NA, Filho JOP, Fiori HH. Exogenous surfactant therapy in pediatrics J Pediatr. 2003;79:S205-S212. http://dx.doi.org/10.1590/S0021-75572003000800010

24. Notter RH. Lung surfactants: basic science and clinical applications. In: Lenfant $\mathrm{C}$, editor. Lung biology in health and disease. $1^{\text {st }} \mathrm{ed}$. New York: Marcel Dekker; 2000;305-8.
25. Romero EJ, Moya FR, Tuvim MJ, Alcorn JL. Interaction of an arteficial surfactant in human pulmonary epithelial cells. Pediatr Pulmonol. 2005;39:167-77. http://dx.doi.org/10.1002/ppul.20166

26. Hickling KG. Best compliance during a decremental, but not incremental, positive end-expiratory pressure trials is related to open-lung positive end-expiratory pressure: a mathematical model of acute respiratory distress syndome lungs. Am J Respir Crit Care Med. 2001;163:69-78. http://dx.doi.org/10.1164/ajrccm.163.1.9905084

27. Frazer DG, Lindsley WG, Rosenberry K, et al. Model predictions of the recruitment of lung units and the lung surface area-volume relationship during inflation. Ann Biomed Eng. 2004;32:756-63. http://dx.doi.org/10.1023/B:ABME.0000030240.83381.63

28. Hickling KG. The pressure-volume curve is greatly modified by recruitment. A mathematical model of ARDS lungs. Am J Respir Critical Care Medicine. 1998;158:194-202.

29. McCann UG, Schiller HJ, Carney DE, Gatto LA, Steinberg JM, Neiman GF. Visual validation of the mechanical stabilizing effects of positive end-expiratory pressure at the alveolar level. J Surg Res. 2001;99:335-42. http://dx.doi.org/10.1006/jsre.2001.6179

30. Halter JM, Steinberg JM,Schiller HJ, et al. Positive-end expiratory pressure after recruitment maneuver presents both alveolar collapse and recruitment/derecruitment. Am J Resp Crit Care Med. 2003;167:1620-6. http://dx.doi.org/10.1164/rccm.200205-4350C

31. Strohmaier W, Trupka A, Pfeiler C, et al. Bilateral lavage with diluted surfactant improves lung function after unilateral lung contusion in pigs. Crit Care Med. 2005;33:2286-93. http://dx.doi.org/10.1097/01.CCM.0000182819.11807.16

32. Hermon M, Golej J, Burda G, et al. Surfactant therapy in infants and children: three years experience in pediatric intensive care unit. Shock. 2002;17:247-51. http://dx.doi.org/10.1097/00024382-200204000-00001

33. Strohmaier W, Marraro G. Surfactant treatment in the ICU: alternative interpretations of existing evidence. Pediatr Anesth. 2006;16:813-5. http://dx.doi.org/10.1111/j.1460-9592.2006.02015.x 


\title{
Ispiranje bronha surfaktantom kao metoda liječenja atelektaze $u$ jedinici intenzivnog liječenja djece
}

\author{
M. Karaman Ilić, G. Madžarac, I. Babić, B. Milavić
}

Cilj je bio ispitati učinak bronhoskopske primjene razrjeđenog surfaktanta u liječenju atelektaze u djece. U ovu prospektivnu studiju je bilo uključeno 18 djece na mehaničkoj ventilaciji koja su neuspješno liječena fizikalnom terapijom i bronhoskopskom aspiracijom. U devetoro bolesnika je nakon bronhoskopske aspiracije apliciran surfaktant u bronh zahvaćenog pluća, dokje u drugih devetoro aplicirana jednaka količina fiziološke otopine. Mjereni su parametri plućne funkcije, PEEP, Ol, a radiološka analiza rtg snimki provodila se prije aspiracije te 6 i 12 sati nakon ispiranja. U obje skupine većina mjerenih parametara pokazala je poboljšanje u odnosu na osnovne vrijednosti. Skupina kojoj je apliciran surfaktant pokazala je značajno poboljšanje u usporedbi s drugom skupinom. Najznačajniji učinak surfaktanta pokazao se na mjerenjima provedenim 12 sati nakon aplikacije ( $p<0,001$ u obje skupine): PEEP 5.22 (SD 0,44) u skupini ispiranoj fiziološkom otopinom prema 3.44 (SD 0,73) u skupini ispiranoj surfaktantom; OI 3,84 (SD 1,13) naspram 2,1 (SD 0,38); srednji talk u dišnom putu (MAP) 8,56 (SD 0,88) naspram 6,33 (SD 0,5). U zaključku, bronhoskopska aspiracija učinkovita je metoda u liječenju atelektaze u jedinici intenzivnog liječenja djece. Terapijski učinak ispiranja bronha razrjeđenim surfaktantom u takve djece mora se potvrditi u daljnjim istraživanjima na većem uzorku.

Ključne riječi: bronhoalveolarno ispiranje; plućni surfaktant; plućna atelektaza; jedinica intenzivnog liječenja djece 